\title{
Vocabulary of Clothes and Jewelry in Studies of Turkic Languages (From the History of the Study of the Issue)
}

\author{
Alfina Tagirovna Shamigulova \\ Munir Idelovich Karabaev \\ Gulfira Rifovna Abdullina \\ Zulfiya Karimovna Ishkildina \\ Sterlitamak branch of the Bashkir State University, Sterlitamak, Russian Federation \\ 453103, Sterlitamak, Lenin Avenue, 47 «a»; Email: munir.karabaev@yandex.ru
}

Doi:10.5901/mjss.2015.v6n5s3p194

\begin{abstract}
This paper analyzes the history of the study of vocabulary of clothes and jewelry in studies of Turkic languages. The vocabulary of of clothes and jewelry of every nation is closely connected with its history, culture and ethnography. Moreover, the names of clothes and jewelry are the most important historical source for the study of the nation's origin and its development, a contact with other ethnic groups because in every historical epoch every nation has developed its own system of fashion, an important element of which is clothes and jewelry. The actual material shows that the composition of the vocabulary of clothes and jewelry consists not only of its own words, but also foreign borrowings. Therefore, having studied the vocabulary formation it is possible to find out early Turkic contacts with the rest the world. From ancient times these thematic groups of the lexical structure of the language were the subject of a research focus of scientists from different branches of science. Resources and scientific literature review on the study of culture, ethnography and language of Turkic peoples shows that lexical items, included in these thematic groups, occupy an important part of the vocabulary of Turkic languages. It is no coincidence that studies both of a linguistic character and humanities areas is the object of our analytical review.
\end{abstract}

Keywords: study, Turkic languages, Bashkir language, thematic group, clothes and jewelry.

\section{Introduction}

One of the key elements of ethnic culture is clothes, which is the basis of tradition, a battery of mentality of a particular ethnic group. Clothes are considered to be no less important part of everyday life, aimed at life necessities because it is the result of human adaptation to the environment. In connection with that, clothes have always been an important adaptive element that has been most successfully helping a person to get used to the new conditions. Clothes and jewelry are the important part of human beingness that is closely connected with climatic conditions of a certain territory, and each nation is historically connected with a certain territory. As the result, lexical units denoting different types of clothes have been forming in the lexical composition of a certain language. As noted above, the certain climatic conditions have led to appearance in every nation of its own types and names of clothes and jewelry, which are in the thematic field of ethnic characteristics.

For the most detailed study of the language problem, the review of the history of its study plays an important role. In this paper for the first time in the Bashkir linguistics sources and scientific literature are subjects of the review, which highlights the vocabulary of clothes and jewelry of the Turkic peoples.

\section{Literature Review}

Vocabulary of clothes and jewelry as a reflection of the material and in part spiritual culture of the nation is brightly presented in the sources and literature of Turkic peoples. Each scientist, who studies ethnography, folklore, history, literature and language of Turkic peoples, to some extent covered clothes and jewelry items of these people, i.e. the lexical layer of the language vocabulary has indirectly been studied. One thing is certain - the review of items of clothes and jewelry of Turkic peoples dates back to the Middle Ages. In this respect, the lexicographical M. Kashgari's work " 
Divanu lugat at-tyurk" is invaluable," which translation means "Dictionary of Turkic languages". Vocabulary of clothes and jewelry (in particular used in the Bashkir language), which we are interested in, is showed in the dictionary, except for the terms of congeniality, warfare, animal husbandry, astronomy, ethnonyms, somatisms, phytonyms, place names, names of metals, minerals, blacksmithing, various games, competitions, utensils, dishes, food, tools, measures of length, weight, money units, the national calendar, and others (used, in particular, in the Bashkir language), including the names of various textiles (Kashgar, 1072-1074).

"Codex Cumanicus" - "Dictionary of the Kipchak language" (XIII c.) for Italian merchants, who do trade business with the Kipchaks, shows a list of terminology with Latin and Persian equivalents. Along with the other terms of construction, architecture, cooking, blacksmithing, metallurgy, training activities, urban life, music, government, medicine, perfume, ladies' room, and, of course, vocabulary of trade, trade operations (up to packaging and transportation of products, etc.) there are some names of clothes and jewelry in this Codex that are characteristic for the Bashkir language (Codex Cumanicus, 1303).

\section{Methods}

For a comprehensive review of the history of the study of vocabulary of clothes and jewelry in Turkological studies we used the descriptive and historical methods in this study, and also the elements of the analysis of sources. We used the descriptive method to collect the data and catalogue it and also to classify the necessary material. The historical approach to the study of the scientific literature concluded the connection of the vocabulary of clothes and jewelry with the history and culture of the people. Moreover, the historical method helped to determine the correlation of the individual names of clothes and jewelry to a specific period in social life. The results may contribute to the development of historical lexicology. Some conclusions can be used in the study of historical grammar of the Bashkir language, ethnography and cultural linguistics of Bashkirs. The practical significance of this study is that the results can be used in the creation of general and specific dictionaries, materials of the article can be used in research works on historical linguistics and works on ethnography.

\section{Conclusion}

\subsection{The history of the study of vocabulary of clothes and jewelry in general Turkic studies of the XIX-XX centuries}

The history of the study of vocabulary of clothes and jewelry in the Turkic languages has been lasting for several centuries. The two-volume "Sravnitilnyi slovar turetsko-tatarskhikh narechiy, so vklyucheniyem upotrebitelnykh slov arabskikh i persidskikh i s perevodom na russkyi yazyk" by L.A. Budagov is of particular interest. This dictionary is based on the general Turkic and inter-Turkic comparative words, which describe the historical, socio-historical, historical and religious, religious and legal, ethnographic features of the Turkic peoples. This lexicographical work, which is explanatory and translated, etymological, and partly encyclopedic, also pays attention to the words which express relationships, wedding ceremonies, folk customs, etc. Here are some examples of the vocabulary related to the clothes and jewelry of the Bashkir language presented in the dictionary:

kashmau (кашмау) is a headdress worn by Bashkir women, it is studded with beads and over the beads with silver or gold coins or tin rings; behind the kashmau, along the back, hangs a cloth studded with beads and coins as well. There is a pointed cap over the kashmau, also studded. The head of unmarried women is covered with a handkerchief. A robe is made of nankeen or red cloth, depending on wealth. Footwear is boots. The old women cover their heads with tastar (a white handkerchief made of calico).

zipun (зипун), or homespun coat, is an English broadcloth. In the Bashkir and Kirghiz language the chikmen can be made of wool, and the rich can have the chikmen made of black cloth, trimmed with lace; the head is covered with a handkerchief or a pointed cap, trimmed with fur; shirts are made of sackcloth and printed cotton, in winter the coat made of sheep or fox skin is worn) (Budagov, 1869).

In the work "Opyt slovarya tyurkskikh narechyi" (V. I-IV. St. Petersburg, 1888-1911; reissued: V. I-IV. Moscow, 1963) by V.V. Radlov, which is considered to be a big achievement of the Turkic lexicography, there are also examples of vocabulary of clothes and jewelry; for example: кошбау [Bschkir, from кош + бay] (Radlov, 1888-1911).

"Drevnetyurkskyi slovar /DTS/" (L., 1969) is truly considered to be a fundamental edition. This work is based on the vocabulary of many Turkic written monuments of the VII-XIII centuries, such as the legend of Oguz-Kagan (XIII C.), "Diwan ul-Lugat at-Turk" by M. Kashgari (XI c.), etc. The DTS includes about 20 thousand lexical units. According to the estimations of the Bashkir lexicologist and scientist of terminology G.G. Kagarmanov, about seven hundred of the Arabic 
lexical units are widely used in the vocabulary of the modern Bashkir language (Kagarmanov, 2002). In addition, this lexicographical work contains a large number of onomastic units (Karabaev et al., 2015).

Analysing the dictionary, we have examined 161 items of vocabulary describing clothes and jewelry. For example: bašmaq (shoe - Bashkir: 'башмак'), biläzük (bracelet - Bashkir. 'беләзек'), bistik 'cotton fibre', böz 'coarse calico', bürük (string, lace for tying a sack or trousers), bürünčük (headdress for women, light shawl), čaruq'chariki', čekin: čekin jïpï 'silk thread', čekräk 'short underwear', čit 'printed cotton', čijdam 'felt', ej 'silk orange cloth', eliglik 'mittens', eškürti 'silk Chinese patterned cloth', etc. (Drevnetyurkskyi slovar, 1969).

In "Etimologicheskiy slovar tyurkskikh yazykov" by E.V.Sevortyan, in which the general Turkic stems were analysed from the semantic and etymologic point of view, the names of clothes and jewelry were mentioned:

етек/etek Turkmen, Turkish, Karelian, Kumyk and some others; етәк/etäk Uzbek, Uigur, етак/etak Uzbek dialect, етак/et’ak Karelian, өтак/öt’ak Karelian, итәк/itäk Tatar, Bashkir, жетак/ğetak Uzbek dialect, eдек/edek Altaic, êdäk Koybalsk, Soyot, uдек/idek Khakass - 'hem' (of a dress, clothes) (Turkmen, Turkish, Karelian, Kumyk, KabardinoBalkarian), 'apron' (Turkish dialect, Uzbek), 'skirt' (Turkish dialect, Tatar dialect), 'dress', 'type of chemise' (Turkish dialect);

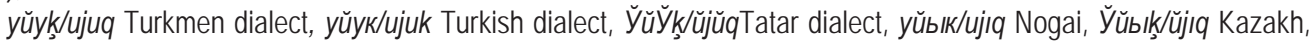
Kazakh dialect, Tatar, Tatar dialect, yŭүк/ujük Balkar - 1. 'socks made of felted cloth' (Turkmen dialect), 'felted stocking', 'cloth stockings' (Tatar dialect), 'wool socks' (Turkish dialect, Kazakh), 2. 'stocking, stockings' (Nogai, Tatar, Bashkir), 3. 'felt boots' (Balkar, Kazakh dialect, Tatar dialect), 4. 'band' (for stockings) (Bashkir dialect) (Sevortyan, 1980).

To sum up, the overview of the Turkic studies of this period shows that the vocabulary related to the clothes and jewelry presents quite a big part.

4.2 The vocabulary related to the clothes and jewelry in contemporary studies based on languages and culture of the Turkic peoples

At the present time researches of this sphere in the Turkic languages is actively continued. There are monographic and dissertation researches devoted to the vocabulary related to the clothes and jewelry based on the modern Turkic languages. G.A. Selimova, for example, in her work "Nakhsko-dagestanskiye zaimstvovaniya v dialektakh kumykskogo yazyka" classifies the borrowed Nakh-Daghestanian words according to their themes and in the separate chapter she examines items, which describe clothes, footwear and jewelry, and analyses their phonetic, semantic, morphological and etymological features (Selimova, 2000).

In the Tatar linguistics the vocabulary related to clothes and jewelry is examined in detail by D.B. Ramazanova in her research "Nazvaniya odezhdy i ukrashenyi v tatarskom yazyke v arealnom aspekte", in which she has analysed phonetic and morphological, lexico-semantic types and areas where this vocabulary is spread. It is notable that in the monograph the factual material is compared with the data taken from the kin and non-kin languages, from the Old Tatar and Old Turkic written languages (Ramazanova, 2002).

T.B. Kokova has analysed this thematic group in detail during her research of vocabulary of the KabardianCircassian language based on the names of clothes. The research gives the general characteristic of the names of clothes, footwear, headdresses, cloths and jewelry, describes the genetic layers, and determines the directions of the further development, role and place of the names of clothes in linguistics (Kokova, 2002).

T.V. Loseva-Bakhtiyarova, in her thesis "Voyennaya leksika tyurkskikh yazykov: Nazvaniya vooruzheniya", mentions a little about the names of clothes. For example: Persian [катаг] 'belt', бил Turkic 'belt'; Persian [Use] ток, кәс̧ә Turkic ток; ammunition belt; Turkic and Arabic synonymy: Turkic jasyq, baslyq - Arabic [miyfar] 'helmet'; Turkic and Mongolian synonymy: Turkic jasyq - Mongolian duyulya 'helmet'; Arabic and Mongolian synonymy: Arabic [miyfar] Mongolian duyulya 'helmet'; Arabic and Russian synonymy: Arabic [miyfar] - Russian Slem; Mongolian and Russian synonymy: Mongolian duyulya - Russian Slem (Loseva-Bakhtiyarova, 2005).

L.F. Tukhbieva, in her scientific work "Leksika odezhdy i golovnykh uborov v tatarskom literarurnom yazyke", determines the linguistic features of the vocabulary of clothes and headdresses, gives the historical and genetic analysis of the names of clothes, headdresses, and classifies them according to the principle of nominalization.

S.N. Burzhumova, in her work "Tyurkskiye zaimstvovaniya v tabasaranskom yazyke" (Burzhumova, 2006), and G.N. Niyazova, in her work "Leksika materialnoy kultury tobolo-irtyshskogo dialecta sibirskikh tatar" (Niyazova, 2008), also examine in separate chapters the semantic, genetic, word-formative aspects of the names of clothes and jewelry.

The R.P. Abdina's research "Leksika traditsionnoy odezhdy v dialektakh khakasskogo yazyka: v sravnenii $\mathrm{s}$ altayskim yazykom" compares the dialects of the Khakass and Altaic languages, emphasizes the integral elements, and at the same time classifies, describes and analyses the names of folk clothes in the dialects of the Khakass language 
using the analysis of the Old Turkic language and other languages (Abdina, 2009).

Besides linguistic studies it is possible to find some information on the vocabulary of clothes and jewelry of Turkic languages in scientific works of historical, ethnographic, cultural and philosophical nature. So L.I. Roslovtseva is one of the first scientists who consider clothes of the Crimean Tatars in the work "Odezhda krymskikh tatar XIX - nachala XX vekov. Istoriko-etnograficheskoe isissledovanie", where she in detail analyzes men's, women's clothes, types of sewing, weaving, jewelry (Roslovtseva, 1999).

The A. I. Savvinova's study "Traditsionnye metallicheskie ukrasheniya yakutov XIX - nachala XX vekov.: Istorikoetnograficheskoe isissledovanie " systematizes, analyzes, defines semantic and social functions of jewelry of the Yakut people, their role and place in the ethnic culture of the Sakha people. Typology is used for classification of jewelry, there is also determined the link of jewelry with the national costume (Savvinova, 1999).

D.F. Madurov in his work "Traditsionnoe chuvashskoe dekorativnoe iskusstvo: Problemy semantiki I stilistiki" in order to define culture, ethnogenesis of the Chuvash people considers the components of clothes and jewelry characteristics of the people (Madurov 2001).

A.I. Mambetova in her thesis titled "Semiotika yuvelirnykh ukrasheniy $v$ traditsionnoi culture Kazachstana" conducts the semiotic and cultural analysis of jewelry of the Kazakh people, considers ethnic and cultural processes that influenced the development of these lexical units, studies the sacred functions of various jewelry (Mambetova, 2005).

T.C. Alekseeva in her dissertation research "Dinamika konstruktsii i dekora altajskogo natsionalnogo kostyuma " describes the features of the formation, development, design, decor of national clothes of the southern and northern Altai, defines similar and distinctive features of costumes of these peoples XVIII - XXI centuries. (Alexeeva, 2008).

The K.M. Yakovleva's work is devoted to vocabulary of clothes and jewelry, "Klassifikatsiya ukrasheniy narodov altajskoi kulturnoi obshchnosti". The paper classifies jewelry of the peoples of Altaic cultural Siberia community XIX early XX centuries on terminology, materials, function, form and place and time of use (Yakovleva, 2011).

\subsection{The history of the study of vocabulary of clothes and jewelry in Bashkir works on ethnography}

As it is well known, traditional folk costumes and jewelry are considered to be the object of the study of several branches of science: history, ethnography, archeology, art history, cultural studies, philosophy, aesthetics, etc. Scientists who arerepresentatives of the above-mentioned areas, as a rule, give a description of the appearance of traditional clothes, pay their attention on development and change of people's clothes when changing epochs, analyze functions of a costume and jewelry.

Ethnographers have studied ethnic and ethno-genetic features of the Bashkir folk costumes as a synthesis of the traditional material and spiritual culture, because traditional clothes often reflect the people's outlook, its aesthetic norms and relations with other nations.

The study of everyday life, including clothes, Bashkirs has a long history. In the notes of travelers who visited Bashkiria from IX to XIII century, there are some references about the Bashkirs.

I.G. Georgi, in particular, noted that "both men's and women's clothes had in their basis the same composition shirts, pants and boots, hats and outerwear were different; the feature of women's costumes were breastplates; neck and chest are covered with scarf, lined scaly with coins; sometimes it is made netlikely from marbles and shells "(Georgi, 1799).

The P.S. Pallas's work is interesting. Although it describes the Bashkir casual clothes cursorily, but at the same time it notes their homespun character. Female hats with a long blade, completely studded with coins are specially marked (Pallas, 1786).

I.I. Lepekhin considers a festive costume, which included colorful cloth marbled robes. According to the records of the author, women wore a headdress kashmau, studded with coins. On feet the Bashkirs wore cloth shoes with leather soles (Lepekhin, 1802).

As the result of his trip to the Orenburg and Astrakhan province in the middle of the XIX century P. Nebolsin gave up a valuable description of the Bashkir home, while mentioning that in the house in prominent places, on the walls, along with saddles, bridles, towels, there were elegant men's and women's clothes ( Nebolsin, 1854).

The M.S. Cheremshanskiy's book, devoted to the description of the Orenburg province in the economic-statistical, ethnographical and industrial relations, draws great attention. In this edition, which was released in 1859, the author focuses his attention on the means of decoration of various pieces of clothes. M.S. Cheremshanskiy says that checmen had mostly red and blue colors, boots and ichigi had mostly scarlet, yellow and black color with embroidery. Elegant shirts kulmyak were decorated with colored silk or paper embroideries, robes zilyan were sewn with colored tape-shaped inserts and small silver coins round the chest and collar (Cheremshanskiy, 1859). 
A. Ignatovich's works contain an interesting information about clothes and jewelry by the Bashkirs, who noted that the men's suit of the Burzyan Bashkirs sometimes has a belt with a bag from embossed leather with two or three bags, one of which is inserted a knife; such belts are sometimes decorated with precious stones and were very expensive. In the women's costume a headdress kashmau and breastplate selter was subjected to a detailed analysis (Ignatovich, 1862).

The V. M. Florinskiy's paper "Bashkiriya i bashkiry," published in the "Vestnil Evropy" in 1874, emphasizes a oblongness of overclothes and underclothes, its wide cut, an obligation to wear head-dress as a special feature of the Bashkir clothes (Florinskiy, 1874).

It should be noted the V.A. Arnoldov's work devoted to life of the Bashkirs, who lived in the southeastern part of the Sterlitamak district. In the essay published in 1894 the scientist notes the dominating use by the Bashkir the factory textiles as the material for fabrication of clothes and features of men's and women's costume. According to the observations of the author, the feature of a women's suit are bright colors, with a predominance of red. The basic set of colors of decorative elements has being limited to red, green and yellow (Arnoldov, 1894).

Among the publications describing the life of the Bashkir people, the monograph of well-known ethnographer, anthropologist, archeologist S.I. Rudenko "Bashkiry: Istoriko-etnograficheskie ocherki", published in two parts, occupies a special place. The author started to gather the material in 1905, continuing his studies for several years. Let's note that materials which were brought by him from the trip across Bashkiria formed the basis of the collection on the ethnography of the Bashkir State Museum of Ethnography in St. Petersburg. The S.I. Rudenko's book is valuable because it contains unique information on many areas of life of the Bashkirs, including national costumes, materials, component parts of clothes, jewelry of the Bashkirs from the end of XVIII to the XX century. The author shows the peculiarities of different types of local women's and men's types of clothes (Rudenko, 1955; 2006).

\subsection{The history of the study of vocabulary of clothes and jewelry in linguistic studies}

Among the linguistic studies on vocabulary of clothes and jewelry, it may be noted the J.G. Kiekbaev's textbook "Lexika i phraseologiya bashkirskogo yazyka" where names of clothes are recorded. For example, a word borrowed from the Russian language: бирсәткә, botinka, kalusha (bashmak ката), galush, ризинкә, кәзәкей, эшләпә, шәпкә, ыштан (tambal), минжәк йәки пинжәк, kamzul, шәл йәки shal, нәкиткә, tuzhurka, kaput, әберкә (балитәк), maçма, sharf, sitsa, satin, бәрзљәуәй, bumazyi, etc. There is the interesting information on etymology of certain names of clothes. For example, the word камсат (бүрек), according to scientist's opinion, dates back to the name of the Kamchatka Peninsula. Kamchatka beaver's skin was considered to be the most valuable skin. In the Bashkir language it is possible to find in dialects the word debet as $\partial \Theta \varnothing \phi \Theta m, \partial \Theta \sigma \Theta m$. The origin of the word J.G. Kiekbaev connects with the name of a certain country. Homeland o goats that give debet 'floss', is an ancient country Tybyt (Tebet). Also the Bashkir word слово кәшимир 'cashmere' goes back to the name of the country of Kashmir (Kiekbaev, 1966).

The G.R. Batyrshina's book "Lexika rodinnogo obryada bashkir" has pointed thematic groups of these lexical items, has disclosed their semantics and etymology. In this study, there are words from the vocabulary of clothes related to the protection of the child from the evil eye, from evil forces. The very first shirt of a child in the Bashkir language is called эт күлдәге 'a dog's shirt'. The dialects have fixed the ways: көсөк күлмәге 'рupру shirt', кырк корама күлдәк 'shirt from forty patches', корама күлдәк 'patchwork shirt', шайтан күлдәге 'bloody shirt' and others. Postpartum rituals include the production of blankets, shirts from 40 different scraps collected from 40 homes; in order to protect from evil spirits a child was settled with earrings (a ritual hырға maғыу) (Batyrshina, 2011).

The S.F. Mirzhanova's monograph "Severo-zapadniy dialect bashkirskogo yuzyka" is devoted to the Bashkir people's spoken language, living with the Tatar and Finno-Ugric population in the north-western regions of Bashkiriya, as well as in the neighboring regions of Tatarstan and the Perm region. Here there is a comparative analysis of northwestern dialects with the literary language and dialects of the Bashkir, Tatar languages. A considerable space of each accent is devoted to the names of clothes and jewelry: karaidelskiy accent ahah - lit. ажы/к 'carnelian, сикмән - lit. сәкмән 'chekmen'; nizhnebelsko-ykskiy accent: камзул, kanzul - lit. kamzul 'coat,' бишенә - lit. ойож энәhe 'knitting needles' etc. (Mirzhanova, 2006).

The N.Kh. Maksyutova's book "Bashkirskie govory, nakhodyashchiesya $v$ inoyazychnom okruzhenii" gives characteristics of argayashskiy, salyutskiy, orenburg accent, defines semantic, morphological, lexical and phonetic features of dialectisms. Examples from the argayashskiy accent: айактун 'pants', гәрәбә - төймә 'beads'. From the orenburg accent: кәптә - кейез̧зән тегелгән аяк кейеме 'shoes made of felt', шимә - tar, семәрле беләз̧ек 'thin patterned bracelet', йалау -elges, әйберз̧әге элмәк 'loop on the collar; zip '(Maksyutova, 1996).

The N.Kh.Ishbulatov's work "Bashkirskiy yazyk i ego dialecty" describes the features of the emergence and 
development of the Bashkir language and its dialects. There we have recorded 47 items of clothes and jewelry: балайтәк (dem., karaid.), катмар, япма, йәрпесәк (sakmar.), мәскәу (ik.) һаңрак (argayash.) - балитәк 'frill'; башай (sred., north-west.), башалай (nugush.), башалтай (ik., sakmar., kyzyl., sr.), баш ойок (salyog.) lit. ойожбаш 'woolen socks', etc. (Ishbulatov, 2000).

"Dialectologicheskiy slovar bashkirskogo yazyka " shows the boundaries of the dialect, determines the meanings, gives equivalents of the literary language. The dictionary includes 495 lexical units from the considered branch of the vocabulary, for example: гүндәк (salyog. 'dress'), иләсә (gajn., mias. 'mittens') керәч (north-west. 'toggle'), кижемамы (north.-west. 'cotton yarn'), көneŭ (karaid., uk. ai. 'quilted coat'), жыйыж (sred. 'scarf') (Dialectologicheskiy slovar, 2002).

R. Shakur, in the work "Bashkirskaya dialektologiya", describes and compares the dialect material, and at the same time gives the names of clothes and jewelry as examples. In the east dialect: сасмаy 'kosopletka'; in the Aisk dialect: кышйаулыл 'shawl', сәсмәу 'kosopletka', кынйырак / киндырак 'footwear made of skin'; in the Miassk dialect: келем 'wool patterned shawl', таһма 'band', селтәр 'woman's vest, decorated with coins, or coral'; in the Uchalinsk dialect (асыуз̧ы): кытай 'necklace', таралғы 'buckle'; in the Salut dialect: бәйз̧әмес 'bandage for shawls', дөл 'velvet', инһәлек 'wide embroidered belt', мәреуәт 'small pearl button' (Shakur, 2012).

\section{Discussion}

Examination of the scientific literature devoted to the study of vocabulary of clothes and jewelry in the Turkic studies has shown that this issue has the long history and at the present time there is a number of different works, which cover this layer of the vocabulary of the language (Karabaev and Abdullina, 2015). It can be explained by the importance of the theme in the study of both language features and history, ethnography and culture of a particular nation. As we known, clothes and jewelry of different ethnic groups are unique and original in their own way. It depends on various factors: history, philosophy, economic relations, way of life and attitudes, aesthetic ideals, traditions, climatic, geographical features of the environment, in which they live (Shamigulova and Abdullina, 2015). The distinctive features of the clothes and jewelry of the Turkic peoples are its spontaneity and artistic integrity at the same time, reflecting the ethnic tastes, ideals and images of artistic and educational interest. At the same time it reveals the specific features of the material and spiritual culture of the people.

\section{Conclusion}

To sum up, the scientific literature on the history, ethnography, archeology, art history, cultural studies, philosophy, aesthetics, linguistics, etc. has studied the traditional clothes and jewelry of Turks in detail. It is noticeable that the mentioned works examine the names of clothes, headdresses, footwear and jewelry in the close connection with the spiritual, ethnographic culture of the Turkic peoples.

Thus, the review of the scientific works allows us to conclude that in the study of Turkic languages the study of vocabulary of clothes and jewelry has a long history. On this issue in a number of Turkic languages there are monographic and dissertation works, and in some languages only the ways of studying the names of clothes and jewelry are mentioned.

The vocabulary of clothes and jewelry is reflected in the works of not only linguistic, but also of historical and ethnographic studies. In the majority of Turkic languages this vocabulary is studied within the colloquial vocabulary, and at the present time in some Turkic languages there are monographic works specifically based on the vocabulary of clothes and jewelry.

\section{References}

Abdina, R.P. (2009) Leksika traditsionnoi odezhdy v dialektah hakasskogo jazyka: v sravnenii s altajskim yazykom: Avtoref. dis. ... kand.filol.n. / R.P. Abdina. Abakan. pp. 20.

Alekseeva, T.P. (2008) Dinamika konstruktsii i dekora altajskogo natsionalnogo kostyuma: Avtoref. dis. ... kand.iskusstvovedeniya / T.P. Alekseeva. Barnaul. pp. 28.

Arnoldov, V.A. (1894) Sanitarno-bytovoi ocherk zhizni bashkir yugo-vostochnoi chasti Sterlitamakskogo uezda Ufimskoi gubernii // Obshhestvo vrachei. Kazanskiy universitet. Dnevnik. Kazan. Vyp.4. pp.227-244.

Batyrshina, R.G. (2011) Leksika rodinnogo obryada bashkir / R.G. Batyrshina. - Ufa: IIJaL UNC RAN. pp. 158.

Башкорт теленең диалекттары һүз̧леге (РФА ӨҒҮ ТТӘИ) (2002) / Төз̧.: М.I. Дилмөхәмәтов, U.F. Нәз̧ерғолов, C.F. Сабирйәнова, Ғ.Ғ. Гәрәева. - Өфө: Кіtap. pp. 432.

Budagov, L.Z. (1869) Sravnitelnyi slovar turetsko-tatarskih narechiy / L.Z. Budagov. SPb. 
Burzhumova, S.N. (2006) Tyurkskie zaimstvovaniya v tabasaranskom yazyke: Dis. ... kand.filol.n. / S.N. Burzhumova. Makhachkala, 2006. pp. 144.

Georgi, I.G. (1799) Opisanie vseh obitayushchih v Rossijskom gosudarstve narodov v chetyreh chastyah / I.G. Georgi. SPb.: Imperatorskaya akademiya nauk, 1799. ch.1. pp. 76. ch.2. pp. 178. ch.Z. pp. 116. ch.4. pp. 383.

Drevnetyurkskiy slovar (1969) / Red. V.M. Nadelyaev, D.M. Nasilov, Je.R. Tenishev, A.M. Shherbak. L.: Nauka. pp. 676.

Ignatovich, A. (1862) Bashkirskaya Burzyanskaya volost // Orenburgskie gubernskie vedomosti / A.Ignatovich. № 6, 7, 8, 9,11,12.

Ishbulatov, N.Kh. (2000) Башкорт теле һәм уның диалекттары / N.Kh Ishbulatov. Өфө: Kitap. pp. 212.

Karabaev, Munir and Abdullina Gulfira (2015) Bashkir anthroponomy // Modern European Researches. -Salzburg, Austria, issue 3. pp. 73-77. ISSN 2311-8806.

Karabaev, M.I., Abdullina G.R. and Ishkildina Z.K. (2015) Bashkir onomatology in the light of modern linguistics // Mediterranean journal of social sciences. Rome-Italy, MCSER Publishing. Vol 6. №3 S3. May. pp. 73-82.

Kashgari М. Девону лугат ит-турк. В 3 т.: Т.1. Tashkent (1963). pp. 445.

Kejekbaev, J.F. (1966) Хәз̧ерге башкорт теленең лексикаһы һәм фразеологияһы / Ж.Ғ. Кейекбаев. - Өфө: Башкортостан китап нәшриәте. рр. 276.

Kokova, T.B. (2003) Problemy sistemnogo analiza otraslevoi leksiki kabardino-cherkesskogo yazyka: Na materiale nazvaniy odezhdy: Dis. ... kand.filol.n. / T.B. Kokova. Nalchik. pp. 213.

Каһарманов, Ғ.Ғ. (2002) Башкорт теленең лексикаһы һәм терминологияһы: укыу әсбабы / Ғ.Ғ. Каһарманов. - Стәрлетамак: СДПИ. рр. 242.

Lepehin, I.I. (1802) Dnevnye zapiski puteshestviya akademika meditsiny doktora Iv. Lepehina po raznym provinciyam Rossijskogo gosudarstva v 1770 g. / I.I. Lepehin. SPb.: pri imp. Akadem. Nauk. ch.2. pp. 338.

Loseva-Bahtiyarova, T.V. (2005) Voennaya leksika tyurkskih yazykov: Nazvaniya vooruzheniya: Dis. ... kand.filol.n. I T.V. LosevaBahtiyarova. M. pp. 293.

Maksyutova, N.H. (1996) Bashkirskie govory, nahodyashhiesya v inoyazychnom okruzhenii / N.H. Maksyutova. Ufa: Bashk.kn.izd-vo. pp. 288.

Mirzhanova, S.F. (1991) Severo-zapadnyi dialekt bashkirskogo yazyka / S.F. Mirzhanova. Ufa: Bashkirskoe knizhnoe izd-vo. pp. 296.

Niyazova, G.N. (2008) Leksika materialnoi kultury tobolo-irtyshskogo dialekta sibirskih tatar: Avtoref. dis. ... kand. filol.n. / G.N. Niyazova. Tyumen. pp. 27.

Nebolsin, P.I. (1845) Rasskazy proezzhego / P.I. Nebolsin. SPb.: Tipografiya shtaba voenno-uchebnyh zavedeniy. pp. 288.

Өмөтбаев, М. Йәдкәр. (2011) Шиғырз̧ар, publitsistik яз̧малар, тәржемәләр, халык ижады өлгөләре, тарихи-этнографик яз̧малар / М. Өмөтбаев. - Өфө. рр. 344.

Pallas, P.S. (1786) Puteshestvie po raznym provinciyam Rossijskoi imperii / P.S. Pallas. - SPb.: 4.2. Kn. 2. pp. 572.

Radlov, V.V. (1911) Opyt slovarja tjurkskih narechij / V.V. Radlov. - v 4-h tomah. I - IV. S.Peterburg, 1888-1911.

Ramazanova, D.B. (2002) Nazvaniya odezhdy i ukrasheniy v tatarskom yazyke / D.B. Ramazanova. Kazan: Izd-vo Master Lajn. pp. 352.

Rudenko, S.I. (2006) Bashkiry: Istoriko-etnograficheskie ocherki / S.I. Rudenko. Ufa: Kitap. pp. 376.

Savvinov, A.I. (1999) Traditsionnye metallicheskie ukrasheniya yakutov XIX - nachala XX vv.: istoriko-etnograficheskoe issledovanie: Dis. ... kand.istor.n. / A.I. Savvinov. Jakutsk. pp. 209.

Sevortyan, Je.V. (1980) Etimologicheskiy slovar tyurkskih yazykov: Obshhetyurkskie i mezhtyurkskie osnovy na bukvu «V», «G»i «D» I Je.V. Sevortyan. - AN SSSR. In-t yazykoznaniya; Red. N. Z. Gadzhieva. M.: Nauka. pp. 395.

Selimova, G.A. (2000) Nahsko-dagestanskie zaimstvovaniya v dialektah kumykskogo yazyka: Dis. ... kand.filol.n. / G.A. Selimova. Mahachkala. pp. 184.

Tuhbieva, L.F. (2006) Leksika odezhdy i golovnyh uborov v tatarskom literaturnom yazyke: Dis. ... kand.filol.n. / L.F. Tuhbieva. Kazan. pp. 218.

Florinskiy, V.M. (1874) Bashkiriya i bashkiry // Vestnik Evropy /V.M. Florinskiy. T.VI. Kn. 12, dekabr. pp. 722-765.

Cheremshanskiy, V.M. (1859) Opisanie Orenburgskoi gubernii v hozyajstvenno-statisticheskom, etnograficheskom i promyshlennom otnosheniyah / V.M. Cheremshanskiy. Ufa. pp. 472.

Shamigulova A.T. and Abdullina G.R. (2015) Zaimstvovannyi plast v leksike odezhdy i ukrasheniy bashkirskogo yazyka // Sovremennye problemy nauki i obrazovaniya. № 1.

Шәкүров, Рәшит (2012). Башкорт диалектологияһһ:: укыу кулланмаһы / Рәшит Шәкүров. Өфө: Kitap. pp. 240.

Yakovleva, K.M. (2011) Klassifikatsija ukrasheniy narodov altajskoi kulturnoi obshhnosti: Dis. ... kand.ist.n. / K.M. Yakovleva. Yakutsk. pp. 201. 